\title{
From Conversion to Ritual Murder: Re-Contextualizing the Circumcision Charge
}

\author{
Paola Tartakoff \\ Rutgers University \\ tartakoff@gmail.com
}

\begin{abstract}
In the 1230s, Christian authorities prosecuted Norwich Jews on charges of having seized and circumcised a five-year-old boy in an effort to convert him to Judaism. In the same decade, English chroniclers began to depict this case as an attempted ritual murder. According to Roger Wendover and Matthew Paris, Jews circumcised the boy with the intention of crucifying him at Easter. This article explores what the near simultaneous development of these two intriguing and seemingly disparate narratives suggests about thirteenth-century Christian perceptions and portrayals of circumcision. In so doing, it ushers research on medieval Christian attitudes toward circumcision into new spheres, deepens understandings of thirteenth-century Christian anxieties about conversion to Judaism, and brings to light a marginal note in the autograph copy of Matthew Paris' Chronica majora that may constitute evidence of evolving Christian views of the relationship between the bodies of Jews' alleged victims and the body of Christ.
\end{abstract}

\section{Keywords}

conversion - circumcision - ritual murder - blood libel - Norwich - anti-Judaism childhood-jewish-christian relations-Matthew Paris-imitatio Christi-circumcision of Christ

In Norwich, England, in 1234, a Christian physician named Master Benedict indicted a Jew named Jacob and twelve other Jews for having, four years earlier, kidnapped and circumcised (circumcidit) his son, Edward. On account of this charge, Jews were incarcerated and put to death. In addition, in 1235 and 1238, 
in outbreaks of anti-Jewish violence that Benedict's accusation likely contributed to fueling, Norwich Jews were beaten and their homes were looted and torched. ${ }^{1}$

Unlike in many other instances during the Middle Ages when Christians accused Jews of seizing a Christian child, in this case, the child in question (who is not to be confused with William of Norwich, whom Jews allegedly crucified in 1144) actually existed and lived to tell his tale. Within days of his circumcision, five-year-old Edward - who may have been the son of a Jewish convert to Christianity - was said to have escaped from Jacob's home and been reunited with his father. ${ }^{2}$ Moreover, in 1234, Edward, now nine years old, testified at Norwich before the king's justices, the prior of Norwich, Dominicans,

1 The main account of Edward's case is given in London, England, the National Archives (TNA), $\mathrm{KB} 26 / 115 \mathrm{~B}, \mathrm{~m}$. 22. This document has a complicated archival history. In the seventeenth century, the number 21 was marked at the foot of the membrane, leading some scholarly works to reference it as being on m. 21. During later conservation work, the number 25 was stamped on the dorse, leading to further confusion. Personal communication with Euan Roger at The National Archives, 5 October 2017. Edward's trial and related documents are published in Walter Rye, "The Alleged Abduction and Circumcision of a Boy at Norwich in 1230," in The Norfolk Antiquarian Miscellany 1 (1877): 312-44, at 322-44; Curia Regis Rolls of the Reign of Henry III, vol. 15 (London, 1972), 333-35; Select Pleas, Starrs, and other Records from the Rolls of the Exchequer of the Jews, 1220-1284, ed. James Macmullen Rigg (London: Quaritch, 1902), xliv-xlvii. An abridged version of the records was published in William Prynne, Short Demurrer to the Jews Long-Discontinued Remitter into England: Part 1 (London, 1656), 19-21; D'Blossiers Tovey, Anglia Judaica: Or the History and Antiquities of the Jews in England (Oxford, 1738), 98-101; Moses Margoliouth, The Jews in Great Britain: Being a Series of Six Lectures (London: J. Nisbet, 1846), 319-22. For discussions of the case, see Rye, "The Alleged Abduction," 312-21; Vivian Lipman, The Jews of Medieval Norwich (London: Jewish Historical Society of England, 1967), 59-63; Zefira Entin Rokeah, "The Jewish Church-Robbers and Host-Desecrators of Norwich (ca. 1285)," Revue des Études Juives 141 (1982): 331-62, at 339-46.

On tensions between Christians and Jews in thirteenth-century England, see Robert C. Stacey, "1240-60: A Watershed in Anglo-Jewish Relations?" Historical Research 61 (1998): 13540; Nicholas Vincent, "Jews, Poitevins, and the Bishop of Winchester, 1231-1234," in Judaism and Christianity, ed. Diana Wood (Oxford: Blackwell, 1992), 119-32; Paul R. Hyams, "The Jewish Minority in Medieval England, 1066-1290," Journal of Jewish Studies 25 (1974): 270-93.

2 On the possibility that Benedict was a Jewish convert to Christianity, see Rye, "The Alleged Abduction," 320-21; Lipman, Jews of Medieval Norwich, 62; Cecil Roth, A History of the Jews in England (Oxford: Clarendon, 1941), 53; Paola Tartakoff, Conversion, Circumcision and Ritual Murder in Medieval Europe, in preparation. On Jews seeking to retrieve apostates' children in medieval Europe, see, for example, Robert C. Stacey, "The Conversion of Jews to Christianity in Thirteenth-Century England," Speculum 67 (1992): 263-83, at 279-80; Cecil Roth, The Jews of Medieval Oxford (Oxford: Clarendon, 1951), 24-25; Aviad Kleinberg, "A Thirteenth-Century Struggle over Custody: The Case of Catherine of Parc-aux-Dames," Bulletin of Medieval Canon Law 20 (1990): 51-68. For an instance in which Jews circumcised the children of a repentant apostate, see Léopold Delisle, "Notes sur quelques mss. du musée britannique," Mémoires de la Société de l'Histoire de Paris 4 (1877): 183-238, at 189. 
Franciscans, and other clerics and laymen. He recounted how, in Jacob's home, one Jew held him and covered his eyes, while another Jew circumcised him with a knife (circumcidit eum quodam cultello). Edward explained that circumcision was not the only rite that these Jews performed. Immediately after circumcising him, they gave him a new name. To choose this name, they placed his foreskin (peciam illam quam sciderant de membro suo) in a bowl of sand and took turns searching for it with small straws. Edward was named Jurnepin (possibly a diminutive of Jurnin, Jurnet, or Joseph) after the Jew who uncovered his foreskin. ${ }^{3}$

Insofar as circumcision and the bestowal of a new name were both integral parts of the traditional Jewish ritual sequence that brought boys and men into the Jewish fold, Edward's deposition suggested that Jacob and his associates had sought to convert Edward to Judaism. Additional testimonies given at Norwich, as well as before the itinerant justices at Catteshall, stated explicitly that Edward's circumcision had been intended to serve as a rite of Jewish initiation. Benedict declared that the Jews circumcised his son because Jacob "wanted to make him a Jew" (voluit ipsum facere Judeum). A woman named Matilda claimed that she found the boy by the river, after he escaped from Jacob's home, "weeping and wailing and saying that he was a Jew." Matilda, the coroners of Norwich, and the former constable, Richard of Fresingfeld, stated that, after Matilda took Edward to her home, Jews repeatedly tried to take Edward back "by force," declaring that "Jurnepin" was "their son" and "their Jew." The constable recounted how the Jews even lodged a formal complaint that "Christians wanted to take away their Jew." In addition, according to the coroners and the constable, the Jews forbade Matilda "to give [the boy] swine's flesh to eat because, they said, he was a Jew."

The allegation that Norwich Jews seized and forcibly circumcised a Christian child in order to convert him to Judaism is startling. During the Middle Ages in Christian Europe, Christians forcibly converted Jews - including countless children - and not the other way around. Indeed, although some Christian authorities claimed otherwise, the very small number of Christians who converted to Judaism appear to have done so in spite of Jewish reluctance to accept

3 Although, to my knowledge, there is no other evidence of naming through searching for the foreskin in sand, it was indeed customary in medieval Ashkenaz to allow the foreskin to fall into a bowl of sand. See Elisheva Baumgarten, "Marking the Flesh: Circumcision, Blood, and Inscribing Identity," Micrologus: Natura, Scienze e Società Medievali. Nature, Sciences and Medieval Societies, vol. 13: La Pelle Umana; The Human Skin (Florence: SISME L ed. Galluzzo, 2005), 313-30, at 320.

4 Curia Regis Roll 115b, 18 Henry III, m. 22. 
converts. ${ }^{5}$ Even the accusation that Jews sought to bring Christian children into the Jewish fold was unusual. To my knowledge, there are no other cases from the thirteenth century. ${ }^{6}$

The Norwich circumcision case appears in five thirteenth-century chronicles. The Chronicle of Bury St. Edmunds and the second continuation of the Chronicle of Florence of Worcester state that, in 1240, "at Norwich, four Jews were drawn by horses and hanged on account of various crimes [but] especially because they circumcised a certain Christian boy according to the rite of the Jews"

5 For an overview of Christian conversion to Judaism in medieval Europe, see Kenneth Auman, "Conversion from Christianity to Judaism in the Middle Ages" (Masters thesis, Yeshiva University, 1977) and Wolfgang Giese, "In Iudaismum lapsus est. Jüdische Proselytenmacherei im frühen und hohen Mittelalter (600-1300)," Historisches Jahrbuch der Görres-Gesellschaft 88 (1968): 407-18. On learned Jewish attitudes toward conversion to Judaism in twelfth- and thirteenth-century Europe, see Ephraim Kanarfogel, Brothers from Afar: Rabbinic Approaches toward Apostasy and Reversion in Medieval Europe (Detroit, 2018) and Ephraim Kanarfogel, "Approaches to Conversion in Medieval European Rabbinic Literature: From Ashkenaz to Sefarad," in Conversion, Intermarriage and Jewish Identity, ed. Adam Mintz and Marc Stern (New York: Michael Scharf Publication Trust of the Yeshiva University Press, 2015), 217-57. On the relationship between Christian charges of Jewish proselytizing and the social realities of conversion to Judaism in thirteenth-century Europe, see Paola Tartakoff, "Conversion and Return to Judaism in Medieval Europe, 1150-1350: Jewish and Christian Perceptions," in Contesting Conversion in the Medieval World, ed. Yaniv Fox and Yosi Yisraeli (New York: Routledge, 2017), 177-94.

6 From the first half of the fourteenth, there are at least four: In a 1304 sermon, the Dominican preacher Giordano da Pisa reported that Jews abducted poor Christian boys, promised them money and circumcised them (li circuncidono). See Racconti esemplari di predicatori del due e trecento, ed. Giorgio Varanini and Guido Baldassarri, 3 vols. (Rome: Salerno, 1990), 2:322-28 (\#167-68). On Giordano da Pisa, see Jeremy Cohen, The Friars and the Jews: The Evolution of Medieval Anti-Judaism (Ithaca: Cornell University Press, 1982), 238-41. In his inquisitorial manual, the Practica inquisitorum heretice pravitatis, the inquisitor of Toulouse, Bernard Gui (d. 1331), noted that Jews circumcised (circuncidunt) Christian children and adults differently from their own children. See Bernard Gui, Practica inquisitionis heretice pravitatis, 5.5.3, ed. Célestin Douais (Paris: Picard, 1886), 289-90. Gui appears to have derived part of this claim from the appendix to an anonymous treatise against the Waldensians in a manuscript from the third quarter of the thirteenth century likely of French origin. This earlier source, however, referred to Jews circumcising only Christian adults differently from Jewish children; it did not refer to Christian children. See Shaye J. D. Cohen, "Between Judaism and Christianity: The Semicircumcision of Christians According to Bernard Gui, His Sources and R. Eliezer of Metz," Harvard Theological Review 94 (2001): 285-321, at 290-93, 306-7, 313. In the 1320s, Jews in Calatayud, Aragon were accused of participating in the circumcision (circumcisio) of a boy who was "the son of a knight." See Barcelona, Arxiu de la Catedral de Barcelona, Codex 126, fols. 81v-82r, 92r. In 1329, the Jews of Tàrrega, Catalonia were prosecuted on charges of having consented to the circumcision (circumcisio) of the sons of a Christian man. See Barcelona, Archivo de la Corona de Aragon, Reg. 434, fol. 136r-v. 
(puerum quemdam Christianum secundum ritum Iudeorum circumciderant). ${ }^{7}$ Three chronicles from the Benedictine abbey of St. Albans in Hertfordshire, however, tell a different story. According to the Flores historiarum of Roger Wendover (d.1236) and the Chronica majora and Historia anglorum of Matthew Paris (d. 1259), Norwich Jews circumcised Edward with the intention of crucifying him at Easter. ${ }^{8}$ In other words, according to Wendover and Paris, Edward's circumcision served as a prelude to-or a first step in — a ritual murder.

Like the charge of attempted forced conversion to Judaism, this weaving of circumcision into a ritual murder narrative appears to have been unprecedented. ${ }^{9}$ In fact, it was not until the late fifteenth century that narratives that combined some kind of genital mutilation with ritual murder gained currency. ${ }^{10}$ The spurious nature of ritual murder accusations aside, it is not

The Chronicle of Bury St. Edmunds, 1212-1301, ed. Antonia Grandsen (London: Nelson, 1964), 10; Florentii Wigorniensis monachi chronicon ex chronicis, ed. Benjamin Thorpe, 2 vols. (London: Sumptibus Societatias, 1849), 2:177.

8 Roger Wendover, Flores historiarum, ed. H. G. Hewlett, 3 vols. (London, 1886-89), 3:101, also in Matthew Paris's entry for the year 1235 in his Chronica majora, ed. H. R. Luard, 7 vols. (London: Longmans \& Co., 1872-83), 3:305-6 and in Matthew Paris's entry for the year 1235 in his c.1253 abridgment of the Chronica majora, the Historia Anglorum, ed. Frederic Madden, 3 vols. (London, 1866-69; repr. Nendeln, Liechtenstein, 1964-71), 2:375. In his entry for the year 1240 in the Chronica majora (whose text up to the year $125^{\circ}$ he had completed by 1251), Matthew Paris offered a more elaborate account, discussed below: Chronica majora, 4:30-31. On the relationship between the work of Roger Wendover and that of Matthew Paris, see Richard Vaughan, Matthew Paris (Cambridge: Cambridge University Press, 1958), 21-34. On the relationship and chronology of the Chronica majora and the Historia Anglorum, see Vaughan, Matthew Paris, 49-77.

9 Prior to the 1230s, Christians occasionally may have associated circumcision with ritual murder. For instance, according to the History of the Monastery of St. Peter's, Gloucester, in 1168 , Gloucester Jews gathered to ritually crucify a boy under the pretense of gathering for a Jewish circumcision. It is hardly clear, however, that circumcision per se sparked this charge; many kinds of Jewish social gatherings spurred such accusations. See the Historia et Cartularium Monasterii Sancti Petri Gloucestriae, ed. W. H. Hart, 3 vols. (London: Longman, Green, Longman, Roberts, and Green, 1863), 1:20-21; English translation by William Barber in Appendix XV of David Welander, The History, Art and Architecture of Gloucester Cathedral (Phoenix Mill, Far Thrupp, Stroud, Gloucestershire; Wolfeboro Falls, NH: A. Sutton, 1991), 6o9-10. On this case, see Joe Hillaby, "The Ritual-Child-Murder Accusation: Its Dissemination and Harold of Gloucester," Jewish Historical Studies 34 (1994-96): 69-109.

10 The claims of Wendover and Paris had little contemporary influence, appearing in only one other chronicle over the course of the next two centuries: Ranulf Higden (d. 1364), Polychronicon, trans. John Trevisa, 9 vols. (London: Longman, Green, Longman, Roberts, and Green, 1865-86; repr. Nendeln, Liechtenstein, 1964), 8:208-9. As we shall discuss below, the alleged ritual murder of Simon of Trent in 1475 gave rise to texts and iconography that depicted Jews wounding the genitals of their purported victims. This trend may, in fact, have contributed to the popularity of Wendover's and Paris's version 
at face value apparent how circumcision made sense to Wendover, Paris, and their thirteenth-century readers in anticipation of crucifixion. Menasseh ben Israel pointed out in the seventeenth century, in his refutation of Wendover's and Paris's accounts of Edward's case, that Jewish circumcision was "a testimony of great love and affection." "If it was intended that, shortly after [circumcision], [the same] child should be crucified," he asked, "to what end [would this child] first [have been] circumcised? ... [Jews presumably would] not dare make a sport of one of the seals of their covenant."11

Important work has been done on medieval Christian views of circumcision as practiced prior to the advent of Christ and among medieval Jews, ${ }^{12}$ as well

of the Norwich circumcision case in the early modern period. At least one of the sixteenth- and seventeenth-century English authors who retold Wendover's and Paris's tale, Robert Fabyan (d. c. 1512), owned and read The Nuremberg Chronicle, with its iconic representation of Simon of Trent (M. T. W. Payne, "Robert Fabyan and the Nuremberg Chronicle," The Library 12 [2011]: 164-69; M. T. W. Payne, "Robert Fabyan's Civic Identity," in The Yorkist Age, ed. Hannes Kleineke and Christian Steer [Donington, UK: Shaun Tyas, 2013], 275-86). Additional links between genital mutilation and allegations of ritual murder emerged in the fifteenth century. The Spanish Franciscan Alfonso de Spina (d. 1491) claimed, for instance, that Jews collected the blood of their alleged victims in the same bowl in which they collected the circumcision blood of Jewish infants (Alfonso de Spina, Fortalitium fidei [Nuremberg: Anton Koberger, 1494], fol. 145). In Endingen in 1462 and in Tyrnau in 1494, Jews were said to use the blood of their purported ritual murder victims to help Jewish infants heal from their circumcisions (Joshua Trachtenberg, The Devil and the Jews [2nd ed., Philadelphia: The Jewish Publication Society, 1983], 149-50).

11 Menasseh ben Israel, Vindiciae judaeorum (London: W. Bickerton, 1743), 11-12.

12 See, for example, Shaye J. D. Cohen, Why Aren't Jewish Women Circumcised? Gender and Covenant in Judaism (Berkeley: University of California Press, 2005); Sean Murphy, "Concern about Judaizing in Academic Treatises on the Law, c. 1130-c. 1230," Speculum 83 (2007): 560-94; Baumgarten, "Marking the Flesh;" Elisheva Baumgarten, "Circumcision and Baptism: The Development of a Jewish Ritual in Christian Europe," in The Covenant of Circumcision: New Perspectives on an Ancient Jewish Rite, ed. Elizabeth Wyner Mark (Boston: University Press of New England/Brandeis University Press, 2003), 114-27; Elisheva Baumgarten, Mothers and Children: Jewish Family Life in Medieval Europe (Princeton: Princeton University Press, 2004); Irven Resnick, Marks of Distinction: Christian Perceptions of Jews in the High Middle Ages (Washington D.C.: The Catholic University of America Press, 2012); Steven Kruger, "Becoming Christian, Becoming Male?" in Becoming Male in the Middle Ages, ed. Jeffrey Jerome Cohen and Bonnie Wheeler (New York: Routledge, 1997), 21-41; Steven Kruger, "The Bodies of Jews in the Late Middle Ages," in The Idea of Medieval Literature: New Essays on Chaucer and Medieval Culture in Honor of Donald R. Howard, ed. James M. Dean and Christian K. Zacher (Newark: University of Deleware Press, 1992), 301-23; Shaye J. D. Cohen, "A Brief History of Jewish Circumcision Blood," in The Covenant of Circumcision, 30-42; David Biale, Blood and Belief: The Circulation of a Symbol between Jews and Christians (Berkeley: University of California Press, 2007); Abraham Gross, "The Blood Libel and the Blood of Circumcision: An Ashkenazic Custom that Disappeared in the Middle Ages," JQR 86 (1995): 171-74; Amanda Cohen, "Medieval Blood 
as on medieval understandings of the circumcision of Christ. ${ }^{13}$ The Norwich circumcision case reminds us, however, that thirteenth-century Christians thought of circumcision also as a rite that Jews could perform on Christians. In exploring the significance of the two intriguing and seemingly disparate thirteenth-century representations of Edward's alleged circumcision-on the one hand, as part of a Jewish effort to convert a Christian child to Judaism, and, on the other, as part of a Jewish effort to commit ritual murder-the present study ushers research on thirteenth-century Christian attitudes toward circumcision into this new sphere.

This essay first considers references to circumcision in thirteenth-century Christian discussions of the seemingly improbable phenomenon of Christian conversion to Judaism. These, I argue, shed light on Christian anxieties about conversion to Judaism and illuminate some of the judicial methods and rhetorical strategies that Christian authorities used to combat it. I next propose several frameworks in which Wendover, Paris, and their thirteenth-century readers might have understood circumcision in the context of a ritual murder. In the course of this discussion, I suggest that a marginal note in the autograph copy of Matthew Paris's Chronica majora may constitute early evidence of evolving Christian views of the relationship between the bodies of Jews' alleged ritual murder victims and the body of Christ. Throughout, I show that the two narratives about Edward's alleged circumcision gave voice to convictions that unquestionably were held by some thirteenth-century Christians, namely, that contemporary Jews direly threatened Christians and Christianity and preyed on the most vulnerable members of the Christian flock. Connoting both physical violence and spiritual corruption, the notion that Jews circumcised Christians reflected the sense that Jewish iniquity knew no bounds.

Myths: Christian Readings and Misreadings of Jewish Practices towards Blood" (PhD Dissertation, University of Pittsburgh, 2010).

13 See, for example, Leo Steinberg, The Sexuality of Christ in Renaissance Art and Modern Oblivion 2nd ed. (Chicago: University of Chicago Press, 1996), 49-56; Caroline Walker Bynum, "The Body of Christ in the Later Middle Ages: A Reply to Leo Steinberg," Renaissance Quarterly 39 (1986): 399-439, published also in Bynum, Fragmentation and Redemption: Essays on Gender and the Human Body in Medieval Religion (New York: Zone, 1992), 79-117; Anthony Bale, Feeling Persecuted: Christians, Jews and Images of Violence in the Middle Ages (London: Reaktion, 2010), 43-45; Resnick, Marks of Distinction, 62-63; Leonard Glick, Marked in Your Flesh: Circumcision from Ancient Judea to Modern America (New York: Oxford University Press, 20o6), 93-96; Andrew Jacobs, Christ Circumcised: A Study in Early Christian History and Difference (Philadelphia: University of Pennsylvania Press, 2012). 


\section{Circumcision and Conversion to Judaism}

From Judaism's earliest beginnings, circumcision was a key marker of Jewish identity. In Genesis, God demanded circumcision of Abraham and his male descendants as a sign of God's covenant with them (Gen 17:9-14). Rabbinic law, which was redacted between the second and sixth centuries CE, stipulated that the identity of one's mother-and not whether or not one was circumciseddetermined if one was Jewish. Yet, circumcision retained tremendous importance. An uncircumcised Jewish man was considered ritually impure. Popular and mystical Jewish traditions deemed circumcision necessary for avoiding individual punishment in the afterlife. Liturgical poems described circumcisions as advancing the collective redemption of the Jewish people. ${ }^{14}$

High medieval Christians were well aware of the Jewish practice of circumcision. ${ }^{15}$ Theologians conceded that, prior to the advent of Christ, circumcision had been spiritually valuable. Following Paul, however, they deemed circumcision as observed by contemporary Jews to be spiritually ob-

14 On the evolution of Jewish constructions of Jewish identity in antiquity, see Shaye J. D. Cohen, The Beginnings of Jewishness: Boundaries, Varieties, Uncertainties (Berkeley, 1999). On the implications within the Jewish community of being uncircumcised, see Cohen, Why Aren't Jewish Women Circumcised?, 184-86 and Micha Perry, "Byzantium's Role in the Transmission of Jewish Knowledge in the Middle Ages: The Attitude toward Circumcision," in Jews in Byzantium: Dialectics of Minority and Majority Cultures, ed. Robert Bonfil, Oded Irshai, Guy Stroumsa, and Rina Talgam (Leiden and Boston: Brill, 2012), 643-57. On circumcision's effects on individual and collective Jewish "salvation," see Elisabeth Hollender, "The Ritualization of Circumcision in Medieval Judaism in Relation to Islam and Christianity: An Overview," Religion 42 (2012): 233-46, at 239-45; Rami Reiner, "On the Practice of Circumcising Miscarried Fetuses: Between Halakhah and Aggadah, Between Custom and Popular Belief," Zion 79 (2014): 453-75; Cohen, Why Aren't Jewish Women Circumcised?, 40-43.

15 Some medieval Christians were familiar also with a variety of traditions surrounding circumcision. In the twelfth century, Rupert of Deutz wrote of the popular Jewish belief that circumcision was required for "salvation" (Anna Sapir Abulafia, "Bodies in the JewishChristian Debate," in Framing Medieval Bodies, ed. Sarah Kay and Miri Rubin [Manchester: Manchester University Press, 1994], 123-37, at 131-32). As noted above, the records of the judicial proceedings relating to Edward's case suggest Christian familiarity with-or at least illuminate one way in which knowledge spread about - the Ashkenazi practice of letting the foreskin drop into a bowl of sand. In his compendium of anti-Jewish and anti-Muslim polemic, the Pugio fidei (c. 1280), the Catalan Dominican Ramon Martí described the Jewish practice of sucking the blood from the wound (au Moyen Age: 'Es-tu encore) (Ramon Marti, Pugio fidei [Leipzig, 1687] part 3, dist. 3, chap. 11, par 18, fols. 613-14, p. 786). Later, there was awareness of the tradition of setting of a chair for Elijah (Daniel Lasker, "Transubstantiation, Elijah's Chair, Plato, and the Jewish-Christian Debate," Revue des Études Juives 143 [1984]: 31-58). 
solete and illustrative of Jewish carnality and stubbornness. ${ }^{16}$ Indeed, circumcision was the sign par excellence of Jewish-Christian difference. As such, it was a focus of Jewish-Christian polemics, and its vocabulary permeated Jews' and Christians' references to one another. Jews took pride in circumcision as a symbol of their faith in the eternity of God's covenant with Abraham, and they disparagingly referred to Christians as "the foreskinned." ${ }^{17}$ Christians referred to Jews as "the circumcised" and to the abrogated Old Law as "the law of circumcision." 18

To Christians, circumcision evoked a quintessentially Jewish act—an act, moreover, that did not necessarily involve only Jews. This perception was evident in word play, as when Christians accused Jews who were said to have clipped coins of "circumcising" currency. ${ }^{19}$ It was perhaps most salient in Christian references to Christian conversion to Judaism. Although rare, conversions to Judaism loomed large in the minds of Christian authorities on account of the affront they posed to Christian supersessionism and the ways they stoked Christian self-doubt. ${ }^{20}$

16 On the evolution of Latin Christian views of circumcision as practiced before the advent of Christ, see Cohen, Why Aren't Jewish Women Circumcised?, 80-92 and Murphy, "Concern about Judaizing." For a succinct presentation of the Pauline foundations of Christian views of circumcision, see Cohen, Why Aren't Jewish Women Circumcised?, 68-73.

17 On medieval Jewish terms for Christians and Christianity, see Anna Sapir Abulafia, "Invectives against Christianity in the Hebrew Chronicles of the First Crusade," in Crusade and Settlement: Papers Read at the First Conference of the Society for the Study of the Crusades and the Latin East, and presented to R. C. Smail (Cardiff: University College Cardiff Press, 1985), 66-72.

18 On Paul's use of this terminology, see Cohen, Why Aren't Jewish Women Circumcised?, 70.

19 See, for example, Matthew Paris, Chronica Majora, 4:632-33; 5:15 and discussions in Historia Anglicana, ed. Bartholomew Cotton and Henry R. Luard (London: London, Longman, Green, Longman and Roberts, 1859), 126; Willis Johnson, "Textual Sources for the Study of Jewish Currency Crimes in Thirteenth-Century England," British Numismatic Journal 66 (1996-1997): 21-32; Sophia Menache, "Matthew Paris's Attitudes toward Anglo-Jewry," Journal of Medieval History 23 (1997): 139-62, at 153-56; Zefira Entin Rokeah, "Money and the Hangman in Late Thirteenth-century England," Jewish Historical Studies 31 (1988-90): 83-109; 32 (1990-92): 159-218.

20 Records from the Cairo Genizah, documents from archives in Catalonia and England, tombstones in Germany, the writings of rabbinic authorities, and proceedings of the medieval inquisition have revealed several dozen cases of (non-slave) Christian conversion to Judaism in medieval Europe. As conversion to Judaism was of necessity clandestine, and as few records of such conversions were produced and even fewer have survived, it is likely that there were more conversions than we shall ever know. See above for bibliography on medieval Christian conversion to Judaism. On Christian religious doubt in medieval Europe and its relation to anti-Judaism and anti-Semitism, see Gavin Langmuir, "Doubt in Christendom," in Gavin Langmuir, Toward a Definition of Antisemitism (Berkeley: University of California Press, 1990), 100-33. 
In broad proclamations about conversion to Judaism as well as in discussions of individual cases, popes, kings, chroniclers, and inquisitors all foregrounded circumcision. For example, in his Speculum ecclesiae (1216), Gerald of Wales wrote about a Cistercian who "had himself circumcised in the Jewish rite." ${ }^{21}$ In a 1233 letter to German prelates, Pope Gregory IX referred to Christians who, "going over to the Jews and following their rites, allowed [themselves] to be circumcised."22 According to the annals of the abbeys of Dunstable and Coggeshall, Matthew Paris's Historia anglorum, a canon of Barnwell, and the chronicler Thomas Wykes (d. c. 1289), an Oxford deacon who married a Jewish woman and was burned at the stake in 1222 had, prior to his marriage, "been circumcised." ${ }^{23}$ In 1254, the Castilian law code known as the Fuero real forbade "any Jew to induce any Christian to turn from his religion or circumcise him."24 Around 1292, the inquisitor Bartolomeo de Aquila informed King Charles II of Naples that Jews were inducing the apostasy of Christians in a particular synagogue where they had recently "circumcised" a Christian. ${ }^{25}$ In 1299, King Philip IV of France commanded the justices of his kingdom to punish Jews who "seduced" Christians and then "circumcised those whom they had seduced." ${ }^{26}$ In 1312, the archbishop of Tarragona heavily fined Jewish communities in Catalonia whom he charged with having aided two German Christians who

For discussions of the complex relationship between the experience of conversion and documents written about it, see Ryan Szpiech, Conversion and Narrative: Reading and Religious Authority in Medieval Polemic (Philadelphia: University of Pennsylvania Press, 2013); Jean-Claude Schmitt, La conversion d'Hermann le juif: Autobiographie, histoire et fiction (Paris: Seuil, 2003), translated into English by Alex J. Novikoff: The Conversion of Herman the Jew, Autobiography, History and Fiction in the Twelfth Century (Philadelphia: University of Pennsylvania Press, 2010); Karl Morrison, Understanding Conversion (Charlottesville, Va.: University Press of Virginia, 1992).

Giraldus Cambrensis, Opera, ed. J. S. Brewer, 8 vols. (London: Longman, Green. Longman, Roberts, and Green, 1873), 4:139.

Solomon Grayzel, The Church and the Jews in the Thirteenth Century, vol. 1 (New York: Hermon Press, 1966 [rev. edn.]), vol. 2 (Detroit: Wayne State University Press, 1989), 1:198 (\#69).

23 On this case, see Frederic William Maitland, "The Deacon and the Jewess; or, Apostasy at Common Law," in The Collected Papers of Frederic William Maitland, ed. Hal Fisher, 3 vols. (Cambridge: Cambridge University Press, 1911), 1:385-406. The various sources describe the deacon as having "circumcised himself," having "caused himself to be circumcised," having "been circumcised," and having "been circumcised according to the Jewish rite."

24 Fuero Real, book 4, title 2, law 2, in Opúsculos legales del rey don Alfonso el Sabio, 2 vols. (Madrid: Real Academia de la Historia, 1836), 2:118.

25 Gennaro Maria Monti, "Da Carlo I a Roberto di Angiò: Ricerche e documenti," Archivio storico per le province napoletane 59 (1934): 137-223, at 175-76.

26 Gustave Saige, Les juifs du Languedoc antérieurement au XIVe siècle (Paris: Picard, 1881), $236\left(\#_{20}\right)$. 
"left the Catholic faith, circumcised themselves in Toledo, and adhered to the Jewish faith."27

This emphasis on circumcision reflected the Christian sense that circumcision constituted the watershed moment in the process of joining the Jewish fold. Circumcision was the only rite associated with becoming a Jew prior to the destruction of the Second Temple in Jerusalem in $70 \mathrm{CE}$; Christians were familiar with it as such from the Bible. ${ }^{28}$ In addition, some Christians were aware that circumcision remained a key element of the process by which Jews in medieval Europe, who followed rabbinic law, effected the conversions to Judaism of men. ${ }^{29}$

This emphasis on circumcision also provides insight into Christian concerns about conversion to Judaism. To Christian authorities who perceived the dominant and ecclesiastically sanctioned Jewish-Christian power dynamicsaccording to which Jews were to be subordinate to Christians - as too often subverted, instances of conversion to Judaism constituted further evidence that Jews wielded inordinate influence. ${ }^{30}$ In this context, it is possible that Christian authorities feared that the willingness of male converts to Judaism to undergo a rite as difficult as circumcision might impress Christian observers and instill or deepen doubts about the superiority of Christianity to Judaism. Jews recognized that circumcision was challenging and could serve as an obstacle to conversion. The author of the thirteenth-century northern European circumcision manual Kelalei ha-Milah, for instance, acknowledged that the prospect of the pain of circumcision might cause an individual to withdraw

27 Die Juden im christlichen Spanien, ed. Yitzhak [Fritz] Baer, 2 vols. (Berlin: Akademie Verlag, 1936. Reprint, London: Gregg, 1970), 1:204-6 (\#166).

28 See discussion in Yair Furstenberg, "The Christianization of Proselyte Baptism in Rabbinic Tradition," in Coping with Religious Change in the Late Antique Eastern Mediterranean, ed. E. Iricinschi and C. Kotsifou, Studies and Texts in Antiquity and Christianity (Tübingen: J.C.B. Mohr, 2017), 1-28.

29 The procedure for conversion to Judaism as established by rabbinic authorities in Babylonia by the fifth century CE is described in the Babylonian Talmud (hereafter, BT), Yevamot $47 \mathrm{a}-\mathrm{b}$. This procedure is depicted also, with substantial variations, in the post-talmudic tractate Gerim 1:1. On the rabbinic conversion ceremony, see Cohen, The Beginnings of Jewishness, 198-238. On medieval rabbis' specifications regarding conversion procedure in northern France, Germany and Spain, see Kanarfogel, "Approaches to Conversion."

30 On Christian concerns about Jewish religious influence, see Paola Tartakoff, "Segregatory Legislation and Jewish Religious Influence on Christians in the Thirteenth Century," in Medieval Minorities: Law and Multiconfessional Societies in the Middle Ages, ed. John Tolan, Capucine Nemo-Pekelman, Jerzy Mazur, and Youna Masset (Turnhout: Brepols, 2017), 265-75. On Jewish material prosperity, population growth and political influence during the Middle Ages, see Robert Chazan, Reassessing Jewish Life in Medieval Europe (Cambridge: Cambridge University Press, 2010). 
from the conversion process. ${ }^{31}$ By the same token, however, some Jewish sources portrayed convert circumcision as evidence of male converts' extraordinary commitment and resolve. A passage in the thirteenth-century northern European compendium of anti-Christian polemic, the Nizzahon Yashan, for example, stated that, when a non-Jewish man "took refuge under the wings of the Divine Presence," in spite of the fact that this involved, among other hardships, "wounding himself by removing his foreskin through circumcision," it demonstrated the convert's certainty that Christianity was "without foundation and that it [wa]s all a lie, vanity, and emptiness." ${ }^{2}$ On account of its theological significance and the sheer nerve that it required, the circumcision of Christian converts to Judaism constituted an exceptionally powerful repudiation of Christianity. Thus, the thirteenth-century Jewish poet Moses ben Jacob portrayed the Christian convert to Judaism and martyr, Avraham ben Avraham of Augsburg (d. c. 1265), as defiantly declaring to his Christian persecutors: "Know that I am without foreskin! ... I circumcised myself to be a Hebrew!"33

The emphasis on circumcision in medieval Christian references to conversion to Judaism points also to a number of ways in which lay and ecclesiastical leaders sought to combat conversion to Judaism. For example, it signals the value of circumcision as verifiable evidence that steps had been taken toward joining the Jewish fold. ${ }^{34}$ Thus, according to Matthew Paris, Christians examined the body of the Oxford deacon, mentioned above, to see if he had been circumcised. ${ }^{35}$ And the testimonies given in the course of the judicial proceedings relating to Edward's case emphasize that Edward's circumcised penis had been seen. Benedict declared that he had shown Edward's body to the justices of Norwich shortly after his son's alleged circumcision and that "it was clear"

31 Zikhron Brit la-Rishonim, ed. Jacob Glassberg (Berlin: vi Hirsch Itzchowski, 1892), 133.

32 David Berger, The Jewish-Christian Debate: A Critical Edition of Nizzahon Vetus (Philadelphia: The Jewish Publication Society of America, 1979), 206-207 (\#211) (=144-45 [\#211] in Hebrew).

33 Israel Davidson, Thesaurus of Medieval Hebrew Poetry, 4 vols. (New York: Ktav, 1924-1933), 1:3263; Abraham Habermann, Gezerot Ashkenaz ve-Zarfat (Jerusalem: Tarshish, 1945), 189-90. On the evolution of medieval Jewish attitudes toward converts to Judaism, see Avraham [Rami] Reiner, "L'attitude envers les prosélytes en Allemagne et en France du XI ${ }^{\mathrm{e}}$ au XIII siècle," Revue des Études Juives 167 (2008): 99-119.

34 Circumcision's verifiability could be useful to Jews, as well, especially as male converts sometimes travelled to Jewish communities where they were not known. At the same time, circumcision's verifiability made it a particularly dangerous rite for converts to Judaism and the Jews who facilitated their conversions. The thirteenth-century German Jewish pietistic work Sefer Hasidim recounts how Jews in a particular locale delayed circumcising a prospective convert for fear of Christian repercussions (Sefer Hasidim, ed. Yehudah Wistinetzki [Berlin: H. Itzkowski, 1891], 77 [\#214]).

Paris, Historia Anglorum, 2:254. 
that Edward had been circumcised. The official of the archdeacon, the coroners of Norfolk and Norwich, and a large group of priests insisted that they, too, had seen Edward's recently circumcised member. ${ }^{36}$

Circumcision mattered to Christian authorities in the context of conversion to Judaism also because, among Christians, the very thought of circumcision could elicit a visceral negative response. As a procedure that involved cutting off the foreskin of the penis (milah), scraping off the remaining membrane (periah), and sucking the blood from the wound (mezizah) - and which permanently bared the tip of the penis-circumcision evoked Christian fear and disgust. ${ }^{37}$ In the twelfth century, Gilbert of Poitiers described circumcision as "great torture." ${ }^{38}$ Peter Abelard cast the Jew in his Dialogue of a Philosopher with a Jew and a Christian as asserting that gentiles found circumcision "abhorrent" and that Christian women would never consent to having sex with Jewish men, "believing that the truncating of this member [wa]s the height of foulness." ${ }^{39}$ William of Auvergne characterized circumcision as "an abominable pollution." ${ }^{\prime 0}$ Two thirteenth-century Iberian anti-Jewish polemicists balked in particular at the practice of mezizah. The Dominican Ramon Martí deemed it "utterly abominable and loathsome" and a fitting punishment for Jewish mouths that blasphemed against Christ. ${ }^{41}$ An anonymous source vulgarly likened mezizah to sexual intercourse, identifying the mouth that sucked the wound with a "cunt." 42 The repeated references in the records of the judicial proceedings of the Norwich circumcision case to Edward's "cut penis" (membrum abscisum) as having been "very swollen and bloody" (valde inflatum et sanguinolentum) undoubtedly resonated with Christian horror at the physical trauma of circumcision..$^{43}$ On account of circumcision's negative connotations, foregrounding circumcision in discussions of conversion to Judaism stressed the repulsiveness of conversion to Judaism. It reinforced Christian

$36 \quad$ Curia Regis Roll 115b, 18 Henry III, m. 22.

37 On the surgical details of circumcision according to rabbinic law, see Cohen, Why aren't Jewish Women Circumcised?, 24-26.

38 Gilbert of Poitiers, Sententiae, in N. M. Häring, "Die Sententie Magistri Gisleberti Pictavensis Episcopi," Archives d'histoire doctrinale et littéraire du moyen âge 45 (1978), 83-180, at 145 .

39 PL 178: 1623D-1624A.

40 William of Auvergne, De legibus, in Opera omnia, 1 (Paris, 1674; repr. Frankfurt am Main: Minerva, 1963), 90, col. 1F.

41 Martí, Pugio fidei, part 3, dist. 3, chap. 11, par 18, fols. 613-14, p. 786.

42 La boca de vestro rabi ... feches cono de muier. Enzo Franchini, Los debates literarios en la Edad Media (Madrid: Ediciones del laberinto, 2001), 227-28, quoted in Resnick, Marks of Distinction, 64 n. 43.

43 Curia Regis Roll 115b, 18 Henry III, m. 22. 
stereotypes of Jews as bloodthirsty and depraved and reminded Christians that the harm caused by conversion to Judaism was both spiritual and bodily.

References to circumcision in Christian discussions of conversion to Judaism did not relate only to the technical realities of circumcision, however. "Circumcision" could be understood more loosely, as well, as metonymy for conversion to Judaism. For instance, in his discussion of Christians "who den[ied] faith in Christ and turn[ed] away to the faithlessness of Jews," the mid-thirteenth-century Bavarian ecclesiastical chronicler known as the Passau Anonymous listed clerics, merchants, craftsmen, and women who had "circumcised themselves." 44 This type of reference to circumcision may point to an additional Christian response to the perceived threat of conversion to Judaism: the rhetorical reduction of conversion to Judaism to a minor (if vile) anatomical operation. ${ }^{45}$ As such, "conversion to Judaism" was a far cry from true religious conversion understood as a spiritual transformation. ${ }^{46}$ In keeping with the Christian tenet that baptism imprinted a permanent character on the soul, ${ }^{47}$ the equation of conversion to Judaism with a mere physical procedure

44 Der Passauer Anonymus. Ein Sammelwerk über Ketzer, Juden, Antichrist aus der Mitte des 13. Jahrhunderts, ed. Alexander Patschovsky, Schriften der Monumenta Germaniae Historica 22 (Stuttgart: Hiersemann, 1968), 1:152. I am grateful to Christine Magin for bringing this source to my attention. On the treatise of the Passau Anonymous, also see Margaret Nickson, "The 'Pseudo-Reinerius" Treatise: The final stage of a thirteenth-century work on heresy from the diocese of Passau," Archives d'histoire doctrinale et littéraire du moyen âge 34 (1967): 255-314.

45 This strategy bears some resemblance to Jewish characterizations of Jewish conversion to Christianity as amounting to a "defilement with putrid water." See, for example, the Mainz Anonymous in Eva Haverkamp, ed., Hebräische Berichte über die Judenverfolgungen während des Ersten Kreuzzugs, Monumenta Germaniae Historica, Hebräische Texte aus dem Mittelalterlichen Deutschland 1 (Hanover: Hahnsche, 2005), 533 (94), English translation in Shlomo Eidelberg, The Jews and the Crusaders: The Hebrew Chronicles of the First and Second Crusades (Hoboken: KTAV, NJ, 1996), 104, and the texts discussed in Susan Einbinder, Beautiful Death:Jewish Poetry and Martyrdom in Medieval France (Princeton: Princeton University Press, 2002), 34-35 and Simha Goldin, "Juifs et juifs convertis au Moyen Âge: 'Es-tu encore mon frère?,' Annales. Histoire, Sciences Sociales 54 (1999): $85^{-74}$, at $863^{-65}$.

46 On medieval Christian understandings of religious conversion as a spiritual journey, see Morrison, Understanding Conversion.

47 On the permanence of baptism and its effects, see, for example, Thomas Aquinas, Summa theologiae, part 3, question 66, article 9: "Baptism imprints a character which is indelible and is conferred with a certain consecration ... This is the view expressed by Augustine, who says that ... 'the sacrament of Christ is not less enduring than [a] bodily mark, since we see that not even apostates are deprived of baptism, since when they repent and return they are not baptized anew [Contra epistolam Parmeniani 2]." In 1255, a council in Valencia specified that persons who had been baptized and confirmed and who then became Muslims or Jews, but who afterward wished to return to Christianity, did not require 
reinforced the sense that it was, in fact, impossible for a Christian to become a Jew. ${ }^{48}$ Edward's case illustrates the emphatic Christian denial that circumcision could turn a Christian into a Jew. Even though Jews allegedly circumcised and renamed Edward and insisted that "he was now a Jew," Christians asserted that the boy had never ceased to be a Christian; "Jurnepin" was actually "Edward" all along. As Benedict declared, the Jews had merely "wanted" to make him a Jew. ${ }^{49}$ Insofar as Christian writers referred to conversion to Judaism simply as "becoming circumcised," they mocked the very notion that a Christian could become a Jew and produced anti-conversion narratives that denied Jews and Judaism a religious victory.

A tale recorded by the Passau Anonymous about a monk who "circumcised himself" doubly derided the carnality of conversion to Judaism. First, it suggested that this particular conversion was motivated and sustained, not by faith, but by attraction to a Jewish woman: When this former monk's brother, a prelate, tearfully implored him to return to Christianity, the former monk stubbornly refused, "on account of love [de amore] of his [Jewish] wife."50 Second, this tale ridiculed the centrality of genital mutilation to conversion to Judaism: Out of spite, the prelate compounded his brother's genital injuries. He had his brother castrated, thereby inflicting on him a "mirror punishment" for both conversion to Judaism and sexual misconduct. ${ }^{51}$ This exemplum also

rebaptism or reconfirmation. Contrition on their part, and the reconciliation of a bishop, sufficed (José Sáenz de Aguirre and Giuseppe Catalani, eds., Collectio maxima conciliorum omnium hispaniae et novi orbis, 5 vols. [Rome: Antonii Fulgonii, 1755], 5:198).

48 It is noteworthy that the Christian contention that Christian converts to Judaism were still Christians mirrored the Jewish opinion that Jewish converts to Christianity were still Jews. On the Jewish view that converts to Judaism were indeed Jews in all respects, see Jacob Katz, "Although He Has Sinned, He Remains a Jew" (in Hebrew), Tarbiz 27 (1958): 203-17; Jacob Katz, Exclusiveness and Tolerance: Studies in Jewish-Gentile Relations in Medieval and Modern Times (Oxford: Oxford University Press, 1961), 69-73. Some medieval Jews did, however, express doubts about the possibility of a non-Jew becoming a Jew. See Szpiech, Conversion and Narrative, 100-101.

49 Curia Regis Roll 115b, 18 Henry III, m. 22.

5o This was a stock trope. Medieval Christians and Jews frequently accused apostates from their respective faiths of apostatizing on account of lust. On Jewish accusations to this effect, see Paola Tartakoff, "Of Purity, Piety, and Plunder: Jewish Converts and Poverty in Medieval Europe," in Converts and Conversion to and from Judaism, ed. Theodor Dunkelgrün and Pawel Maciejko (Philadelphia: University of Pennsylvania Press, forthcoming).

$5^{1}$ On the concept of "mirror punishments," see Rolf Bremmer, "The Children He Never Had; the Husband She Never Served: Castration and Genital Mutilation in Medieval Frisian Law," in Castration and Culture in the Middle Ages, ed. Larissa Tracy (Cambridge: Cambridge University Press, 2013), 108-30, at 111. On castration as retribution for sexual misdeeds in medieval Europe, see Larissa Tracy, Introduction to Castration and Culture, 1-28, at 22; and Larissa Tracy, "'Al defouleden is holie bodi': Castration, the Sexualization 
deprecated Jewish women, and Jews in general, as lascivious: When, on account of the castration, the Jewish wife was no longer able to have sex with the prelate's brother (cum non posset cognoscere), she spurned him. At this point, having been rejected by his wife, the circumcised and castrated former monk return to Christianity (reversus est ad fidem). ${ }^{52}$ According to the Passau Anonymous, true inner conversion to Judaism was, despite outward appearances, a perverse delusion.

These observations about the centrality of references to circumcision in thirteenth-century Christian discussions of conversion to Judaism attest to a range of Christian perceptions and portrayals of Jews circumcising Christians. First, they suggest that Christian authorities viewed circumcision as a particularly noxious element of actual Jewish conversion procedure. Circumcision physically wounded male converts and, insofar as convert circumcision might impress Christian observers and sow doubts in their minds about the truth and superiority of Christianity, it bore the potential to spiritually harm the Christian flock at large. Second, these observations illuminate how Christian authorities could make use of circumcision in their efforts to combat conversion to Judaism. As verifiable evidence that steps had been taken to go over to Judaism, circumcision could be critical in the process of intercepting and punishing conversions. Moreover, as circumcision connoted the obsolescence and carnality of Judaism as well as Jewish cruelty and depravity, references to the rite intensified horror at conversion to Judaism. Finally, insofar as Christian sources equated the process of conversion to Judaism with circumcision, they characterized conversion to Judaism as merely external and devoid of spiritual substance, reinforcing the sense that it was ultimately impossible for a Christian to become a Jew.

\section{Circumcision and Ritual Murder}

Between about 1236 and 1253, the English chronicler Roger Wendover and his successor at St. Alban's Abbey, Matthew Paris, recorded two accounts of Edward's case. ${ }^{53}$ According to both, Norwich Jews circumcised Edward, not in order to bring him into the Jewish community, but in anticipation of crucifying him. The first account, which is found in the entry for the year 1235 in

of Torture, and Anxieties of Identity in the South English Legendary," in Castration and Culture, 87-107.

$5^{2} \quad$ Der Passauer Anonymus, 1:152.

53 On the relationship between the work of Wendover and Paris, see above. 
Wendover's Flores historiarum and repeated in the entries for the year 1235 in Paris's Chronica majora and Historia anglorum, is brief. It states that "seven Jews, who had circumcised a certain boy at Norwich, whom they had secretly stolen away, and whom they had hidden from the sight of Christians for a year, wanting to crucify him at Easter, were brought before the king at Westminster." The Jews confessed their crimes and were found guilty and imprisoned. ${ }^{54}$ The second account, which is found in Paris's entry for the year 1240 in his Chronica majora, incorporates more details from the records of the judicial proceedings, including Edward's renaming, a description of Edward's reunion with his father, and the reasons for the case's final adjudication by ecclesiastical authorities. According to this account:

Jews circumcised a Christian boy in Norwich. Having circumcised him, they named him Jurnin. They kept him, however, in order to crucify him as an insult to Jesus Christ crucified. The father of the boy, however, from whom the Jews had secretly stolen the boy, having diligently searched for his son, found him confined in the Jews' custody. With jubilant cries, he pointed to his son, whom he thought he had lost, who was wickedly confined in a certain Jewish chamber. When so great a crime came to the attention of Bishop William of Ralegh, a prudent and circumspect man, and some other nobles, all the Jews of that town were seized, lest, through the neglect of Christians, so great an injury to Christ should go unpunished. And when [the Jews] wanted to place themselves under the protection of royal authority, the bishop said: "These matters regard the church. They are not to be dealt with by the royal curia, as the case concerns circumcision and the wounding of the faith." Four of the Jews were found guilty of the aforesaid crime. First, they were dragged by the tails of horses, and then they were hanged by the gallows, where they exhaled the wretched remains of life. ${ }^{55}$

We cannot ascertain how these accounts of Edward's case-on whose commonalities the following pages shall focus-first came into being. It is possible that, in portraying the Norwich circumcision case as an attempted ritual murder, Wendover and Paris conflated it with one of the first documented allegations of ritual murder, which arose in Norwich also, a century prior. Writing during the third quarter of the twelfth century, the Benedictine monk Thomas of Monmouth claimed that Norwich Jews crucified a boy named William in

54 Wendover, Flores, 3:101; Paris, Chronica, 3:305-6; Paris, Historia, 2:375.

55 Paris, Chronica, 4:30-31. 
$1144 .{ }^{56}$ Such a conflation, however, seems unlikely. Wendover and Paris do not appear to have been well informed about William's case. In all of their writings, there is only one vague and brief reference to it. In his continuation of Wendover's Flores historiarum, Paris noted succinctly that, in 1144, "a certain boy was crucified by the Jews at Norwich." ${ }^{57}$ Moreover, Paris composed this part of his continuation of Wendover's Flores historiarum after he and Wendover wrote their accounts of the Norwich circumcision case, suggesting that Wendover and Paris might not yet have known about William when they wrote about Edward. ${ }^{58}$

The reframing of the Norwich circumcision case as an attempted ritual murder need not have required a coincidence of place. By the 1230s, the charge of ritual murder was a stock anti-Jewish calumny across Western Europe, ${ }^{59}$ and it was one that Matthew Paris energetically propagated ${ }^{60}$ Moreover, thirteenth-

$5^{6}$ The scholarship on William of Norwich is extensive. Salient contributions include Gavin Langmuir, "Thomas of Monmouth: Detector of Ritual Murder," Speculum 59 (1984): 82046 (published also in Langmuir, Toward a Definition, 209-36); John M. McCulloh, "Jewish Ritual Murder: William of Norwich, Thomas of Monmouth, and the Early Dissemination of the Myth," Speculum 72 (1997): 698-740; Hannah Johnson, Blood Libel: The Ritual Murder Accusation at the Limit of Jewish History (Ann Arbor: University of Michigan Press, 2012); E. M. Rose, The Murder of William of Norwich: The Origins of the Blood Libel in Medieval Europe (Oxford: Oxford University Press, 2015). Miri Rubin has published a new translation and edition of Thomas of Monmouth's vita of William: The Life and Passion of William of Norwich (London: Penguin, 2014).

57 Matthew Paris, Flores historiarum, ed. H. R. Luard, 3 vols. (London: Eyre and Spottiswoode, 1890), 2:65.

58 On the relationship and chronology of Matthew Paris's Flores historiarum to his other works, see Vaughan, Matthew Paris, 92-109. On the limited circulation of information about William's case during the Middle Ages, see McCulloh, "Jewish Ritual Murder," 711-17; Gain Langmuir, "Historiographic Crucifixion," in Langmuir, Toward a Definition, $282-98$, at 286 .

59 In addition to the sources cited above, key scholarly contributions regarding the early development of this charge include Israel Yuval, "Vengeance and Damnation, Blood and Defamation: From Jewish Martyrdom to Blood Libel Accusation" (in Hebrew), Zion 58 (1993): 33-96. On medieval Jewish responses to ritual murder accusations, see Israel Yuval, “'They tell lies: you ate the man': Jewish Reactions to Ritual Murder Accusations," in Religious Violence Between Christians and Jews: Medieval Roots, Modern Perspectives, ed. Anna Sapir Abulafia (New York: Palgrave, 2002), 86-106. For an overview of the spread of related charges, see Anna Sapir Abulafia, Christian-Jewish Relations 10oo-1300:Jews in the Service of Medieval Christendom (Harlow, UK: Longman, 2011), 167-88.

6o Paris is known, for instance, for a particularly chilling account of the alleged murder of Hugh of Lincoln (1255), whose "martyrdom" was later celebrated in French and English ballads and Chaucer's "Prioress's Tale." On Paris as a historian, see Vaughan, Matthew Paris, 125-58; Björn Weiler, "Matthew Paris on the Writing of History," Journal of Medieval History 35 (2009): 254-78. On medieval chronicle-writing more generally, see Chris 
century accusations to the effect that Jews harmed Christian children in a variety of ways not uncommonly evolved into tales of crucifixion. For instance, whereas the Hampshire Eyre Rolls specified that Winchester Jews mutilated a one-year-old in $1232{ }^{61}$ the Annals of Winchester stated that Winchester Jews "crucified" this boy. ${ }^{62}$ It is thus conceivable that, when writing about the Norwich circumcision case, Wendover and Paris appended the intent to crucify reflexively.

In ascribing the intent to crucify Edward to the Jews who allegedly circumcised him, Wendover and Paris provided a clue to one of the ways in which they and their thirteenth-century readers might have conceived of the purported circumcision. If they considered crucifixion a predictable culmination to events that began with the abduction and circumcision of a Christian boy, it would seem to follow that they viewed the alleged circumcision itself as a form of abuse. Indeed, in transposing circumcision into the imagined plane of ritual murder, they could have drawn on Christian views of circumcision as a quintessentially Jewish form of violence. An illuminated initial in a Bible that was produced in Canterbury, England for the Benedictine abbot Robert de Bello within a decade of the Norwich legal proceedings vividly conveys the sense that Jews circumcised Christian boys in order to harm them (figure 1). ${ }^{63}$ In the foreground of this image, a swarthy, hairy, beak-nosed, grimacing man, dressed in red, crouches before three tall, fair, naked boys who stand in a cluster on the right. With his left hand, the brutish man draws forth from below the penis of the boy who is closest to him. With his right hand, he brings a small knife with a curved blade to the top of the tip of the boy's penis. The boys gaze at flowing blue water in the upper left, while standing on an undulating red substance. From the textual context, it is clear that this image depicts Joshua circumcising the Israelites who had been born in the wilderness after leaving Egypt (Joshua $5: 2-9)$. These younger Israelites gaze at the Jordan River, while standing on

Given-Wilson, Chronicles: The Writing of History in Medieval England (Hambledon and London: Bloomsbury, 2004). On Matthew Paris's attitudes toward Jews, see Stephen D. Benin, "Matthew Paris and the Jews," Proceedings of the World Congress of Jewish Studies, division B, vol. 2: The History of the Jewish People (1989), 61-68; Menache, "Matthew Paris's Attitudes;" Kate McGrath, "English Jews as Outcasts or Outlaws: The Ritual Murder of Little St. Hugh of Lincoln in Matthew Paris's Chronica Majora" in British Outlaws of Literature and History: Essays on Medieval and Early Modern Figures from Robin Hood to Twn Shon Catty, ed. Alexander Kaufman (Jefferson, NC and London: McFarland, 2011), 11-27; Stacey, "1240-60: A Watershed in Anglo-Jewish Relations?," 148-50; Hames, "The Limits of Conversion," 46-49.

61 PRO, MS JUST 1/775, m. 20; C.C.R. 16 Henry III (1231-1234), m. 8.

62 Annales monastici, ed. Henry Richards Luard, 5 vols. (London: Longman, 1864-69), 2:86.

63 The Bible of Robert de Bello. London, British Library, Burney 3, fol. gor. 
the dry ground at Gilgal. The polemical overtones of this illuminated initial, however, are unmistakable. Indeed, this image may be read as depicting a malevolent Jew who is circumcising defenseless Christian boys. ${ }^{64}$

In transposing circumcision into the imagined plane of ritual murder, Wendover, Paris, and their thirteenth-century readers could have drawn also on familiarity with genital mutilation as a particularly cruel and humiliating form of retribution among medieval Christians. Peter Abelard was castrated for his illicit love affair with his pupil Heloise, for example. He explained in his Historia calamitatum that Heloise's uncle and his kinsmen "cut off those parts of [his] body with which [he] had done that which was the cause of their sorrow." Abelard, moreover, took his own revenge by having two of the men who were responsible for his castration genitally mutilated and by having their eyes gouged out (oculis et genitalibus privati sunt). ${ }^{65} \mathrm{~A}$ record from an eyre court held in Lincoln, England in 1202 provides another example of punitive castration. It recounts how a Christian husband and wife captured and beat a Christian man and each cut off one of his testicles and then dumped him on a public road. The court acquitted the assailants, suggesting that it sympathized with them. Possibly, the man whom the couple castrated had sexually assaulted a member of their family. ${ }^{66}$ In the same year, a Christian man named Robert of Sutton accused a Jew from Bedford, England named Bonefand of having "wickedly had [his nephew, Richard,] emasculated" (nequiter fecit ementulare) and thereby caused him to die. ${ }^{67}$ It has been suggested that Bonefand in fact circumcised Richard in the context of converting him to Judaism. ${ }^{68}$ It is true that Christian sources sometimes blurred the distinction between circumcision and other types of genital mutilation. ${ }^{69}$ Given the currency of punitive

64 In addition, this image may be read as juxtaposing circumcision to baptism. As if to draw the viewer's attention to the dichotomy between circumcision and baptism, the boy who is about to be circumcised points down with his left hand to his impending circumcision, and perhaps to what may be the blood of circumcision on the ground below. With his right hand, he gestures upward toward the glistening water. Elad Zamir has suggested further that this image may juxtapose the Old Law and the New. In this reading, the red substance on the ground may represent the blood of Christ. The water may represent the New Dispensation, ushered in by Christ, who was baptized in the Jordan River and whose followers replaced circumcision with baptism (personal conversation, 21 June 2017).

65 Peter Abelard, Historia calamitatum, Chapter 7.

66 The Earliest Lincolnshire Assize Rolls, 1202-1209, ed. Doris Mary Stenton (London: Lincoln Record Society, 1926), 773-75.

67 Select Pleas of the Crown, vol. 1, AD 1200-1225, ed. F. W. Maitland (London: B. Quaritch, 1888), 26.

68 Joseph Jacobs, Jews of Angevin England (London: David Nutt, 1893), 216-17.

69 On associations between circumcision and castration in Roman law, see Ra'anan Abusch, "Circumcision and Castration under Roman Law in the Early Empire," in The Covenant 


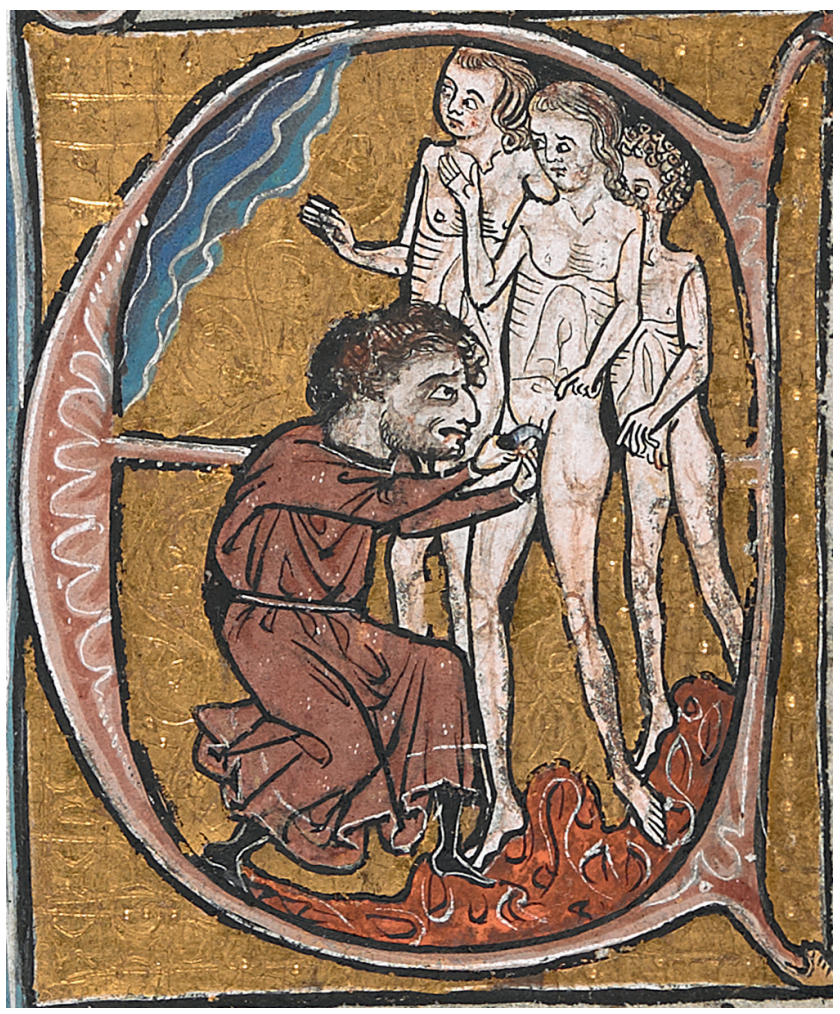

FIGURE 1 Detail from the Bible of Robert de Bello, c. 1240-1253.

London, The British Library, Burney 3, fol. gor.

(C) BRITISH LIBRARY BOARD

genital mutilation, however, a literal reading of this source seems warranted. It is likely that Bonefand had Robert's penis and testicles removed in order to take revenge on him. ${ }^{70}$ This would explain why Bonefand paid the king one

of Circumcision, 75-86. On parodies of circumcision as castration in fourteenth-century Italian theatre, see Claudine Fabre-Vassas, The Singular Beast: Jews, Christians and the Pig, trans. Carol Volk (New York: Columbia University Press, 1997), 113-14. In the fifteenth century, written and iconographic sources often blurred the lines between circumcision, castration, and cutting off the penis and testicles. In 1476, for example, when Christians in Regensburg interrogated Jews about an alleged ritual murder, they asked them: "How was the foreskin on the penis cut off and which Jews cut off the penis?" (R. Po-chia Hsia, The Myth of Ritual Murder: Jews and Magic in Reformation Germany [New Haven: Yale University Press, 1988], 74).

70 On "emasculation" as referring to the removal of the penis and testicles during the Middle Ages, see Yves Ferroul, “Abelard's Blissful Castration," in Becoming Male in the Middle Ages, ed. Jeffrey Jerome Cohen and Bonnie Wheeler (New York: Routledge, 2000), 129-49. 
mark for a trial before a jury, why the jury acquitted Bonefand, and why Robert was found guilty of a false appeal. ${ }^{71}$ In 1247 , in the southeastern French town of Valréas, Christians castrated Jewish men (virorum extractis testiculis) —and tortured them and Jewish women in additional ways - until the Jews confessed to having crucified a two-year-old girl. ${ }^{72}$

Understood as a type of abuse, circumcision could have fit well in a ritual murder narrative. These narratives were remarkably fluid, and they portrayed Jews as tormenting their victims in a wide variety of ways. ${ }^{73}$ According to Thomas of Monmouth's vita of William of Norwich, for example, Jews forced a prickly device known as a "teasel" that was used to finish woolen cloth into their victim's mouth. ${ }^{74}$ According to the History of the Monastery of St. Peter's, Gloucester, in 1168, Gloucester Jews tortured a boy named Harold "with extreme cruelty." "Placing him between two fires, they severely burned his sides, back and buttocks ... They put molten wax in his eyes as well as his ears ... They also knocked out his front teeth." 75 Moreover, Christians commonly claimed that Jews mutilated their victims. According to a manuscript from the second half of the thirteenth century, in 1183, Jews in Bristol cut off the nose and upper lip of a boy named Adam, whom they subsequently crucified in a latrine. ${ }^{76}$ In the very same decade as the Norwich circumcision case, genital mutilation surfaced in another English ritual murder narrative: According to the Hampshire Eyre Rolls, in 1232, Winchester Jews gouged out the eyes and

$71 \quad$ Select Pleas of the Crown, 1:26.

72 Grayzel, The Church and the Jews, 1:264 n. 2.

73 On ritual murder as illustrating Jews' "cruelty ... which should be detested and abhorred," see the Burton Annals on Hugh of Lincoln (Annales monastici, ed. Henry R. Luard, 3 vols. [London: Longman, 1864], 1:340-44) and the discussion in Daniel Baraz, Medieval Cruelty: Changing Perceptions, Late Antiquity to the Early Modern Period (Ithaca: Cornell University Press, 2003), 76-81.

74 Life and Passion, 16.

75 Historia et Cartularium, 1:20-21, English translation in Welander, The History, 6o9-10.

76 London, British Library, MS Harley 957, published in Christoph Cluse, "Fabula Ineptissima: Die Ritualmordlegende um Adam von Bristol nach der Handschrift London, British Library, Harley 957," Aschkenas: Zeitschrift für Geschichte und Kultur der Juden 5:2 (1995), 293-330, at 305-27. On this case, also see Robert C. Stacey, "'Adam of Bristol' and Tales of Ritual Crucifixion in Medieval England," Thirteenth-Century England XI: Proceedings of the Gregynog Conference, ed. Bjorn Weiler, Janet Burton and Philipp Schofield (Woodbridge: Boydell \& Brewer, 2007), 1-15; Robert C. Stacey, "From Ritual Crucifixion to Host Desecration: Jews and the Body of Christ," Jewish History 12 (1998): 11-28; Hames, "The Limits of Conversion." 
heart and "removed the testicles" (testiculis abscisis) of a boy whom they eventually strangled. ${ }^{77}$

Although nothing in Wendover's or Paris's accounts precludes understanding circumcision as a form of torture, this interpretation is not entirely satisfactory. First, had circumcision been intended to function primarily as a form of torture, one might expect Wendover or Paris to have described the alleged circumcision in gory terms, possibly together with other types of abuse. Paris was certainly capable of portraying ritual murders in chilling detail, as he did in his account of the case of Hugh of Lincoln (1255). He might even simply have echoed the many references to Edward's penis in the records of the judicial proceedings as "very swollen and bloody." Yet, neither Paris nor Wendover gave any indication that the alleged circumcision was particularly barbarous, nor did either chronicler claim that Norwich Jews did anything else to the boy, other than hide him away for eventual crucifixion. Second, had circumcision been intended to function simply as a form of torture, one would not expect Paris to have reported that, "having circumcised [the boy], [the Jews] re-named him Jurnin."78

The pairing of circumcision with the bestowal of a new name suggests another way of understanding the role of circumcision in Wendover's and Paris's accounts of the Norwich case. In medieval Christian thought, the circumcision of Christ - which the Gospel of Luke portrays as the occasion for Christ's naming (2:21) — had powerful theological meaning. It was understood as demonstrating that Christ was fully human and as adumbrating — and even initiating - Christ's passion. ${ }^{79}$ During the thirteenth century, in the context of increasing theological investment in Christ's humanity and the flourishing of affective piety, Christ's circumcision assumed heightened devotional importance. Alleged fragments of the foreskin of Christ were venerated as holy relics, ${ }^{80}$ and Christ's circumcision began to figure in devotional meditation as the first of the "Seven Sorrows of Mary."81 Around 126o, the Italian chronicler Jacobus

77 London, Public Record Office (PRO), MS JUST 1/775, m. 20. On this case, see Vincent, "Jews, Poitevins, and the Bishop of Winchester," 128-29.

78 Paris, Chronica, 4:30-31.

79 See Steinberg, The Sexuality of Christ, 49-56; Bynum, "The Body of Christ," 399-439; Bynum, Fragmentation and Redemption, 91-92; Resnick, Marks of Distinction, 62-63; Glick, Marked in Your Flesh, 93-96.

8o Robert P. Palazzo, "The Veneration of the Sacred Foreskin(s) of Baby Jesus-A Documented Analysis," in Multicultural Europe and Cultural Exchange in the Middle Ages and Renaissance, ed. James P. Helfers, Arizona Studies in the Middle Ages and Renaissance 12 (Turnholt: Brepols, 2005), 155-76.

81 Manuel Trens, María: Iconografía de la Virgen en el arte español (Madrid: Plus Ultra, 1946), $223-32$. 
de Voragine re-affirmed in his widely disseminated collection of saints' lives known as the Golden Legend that Christians celebrated the feast of Christ's circumcision (January 1), among other reasons, because it marked the first time Christ shed his blood for humanity and, thus, the start of redemption. ${ }^{82}$

Thirteenth-century Christians sometimes imagined that, when Jews committed ritual murder, they sought closely to parody the passion of Christ. The Anglo-Saxon Chronicle noted, for instance, in regard to the case of William of Norwich, that Jews tortured William "with all the tortures with which our Lord was tortured." 83 In his Chronica majora, Matthew Paris described the precise correspondence between the tortures that Jews allegedly inflicted on Hugh of Lincoln and those that Christ endured. Paris wrote that Lincoln Jews appointed one Jew to serve as a judge, "like Pilate," and that the Jews scourged Hugh "till the blood flowed," crowned him with thorns, mocked him, spat upon him, insulted him and, finally, crucified him and pierced his heart with a spear. ${ }^{84}$

In the context of a parody of Christ's passion, circumcision could serve as a parody of Christ's circumcision, understood as the first step in Christ's passion. This is, in fact, how the alleged circumcision of two-year-old Simon of Trent-whom Jews were said to have ritually murdered in 1475-was explained in the 1475 Geschichte des zu Trient ermordeten Christenkindes, printed by Albertus Duderstadt/Albrecht Kunne. The text accompanying the woodcut depicting a Jew cutting Simon's penis stated that the Jew performed a "circumcision" (Beschneidung) in mockery of Christ's "first bloodshed" (erste plut vergiessung). ${ }^{85}$

In Wendover's and Paris's accounts of the Norwich case as well, circumcision could have been understood as a reenactment of the first stage in Christ's

82 Jacobus de Voragine, The Golden Legend, trans. William Granger Ryan, 2 vols. (Princeton: Princeton University Press, 1993), 1:74. By the early fourteenth century, in texts and images, the arma Christi (instruments of Christ's passion) began to include the knife used in Christ's circumcision. See Sara Lipton, Dark Mirror: The Medieval Origins of Anti-Jewish Iconography (New York: Metropolitan Books, 2014), 227; Anthony Bale, The Jew in the Medieval Book: English Antisemitisms 1350-1500 (Cambridge: Cambridge University Press, 2006), 178.

83 The Anglo-Saxon Chronicle, ed. Dorothy Whitelock (New Brunswick: Rutgers University Press, 1961), 200.

84 Mathew Paris, Chronica majora, 5:516-19. On the case of Hugh of Lincoln, see David Carpenter, "Crucifixion and Conversion: King Henry III and the Jews in 1255," available online at http://www.finerollshenry3.org.uk/content/month/fm-01-2010.html and http:// www.finerollshenry3.org.uk/content/month/fm-02-2010.html; Gavin I. Langmuir, "The Knight's Tale of Hugh of Lincoln," Speculum 47 (1972): 459-82; McGrath, "English Jews as Outcasts or Outlaws," 11-27.

85 Quoted in Areford, The Viewer, 198, 222 n. 98. 
passion. This understanding of circumcision would not have been at odds with the view that circumcision was an expression of Jewish cruelty. Especially in subsequent centuries, Christian artists sometimes cast Christ's circumcision as a grotesque Jewish attack. ${ }^{86}$ However, this interpretation, too, leaves questions unanswered. For instance, if, in the narratives of Wendover and Paris, circumcision was a parody of the first step in Christ's passion, where were the other elements of the passion leading up to crucifixion? And why did Wendover, Paris, and other thirteenth—and fourteenth-century authors not cast Jews as circumcising other ritual murder victims, as well?

Or did they? It is possible that, in one other instance, they did. In his edition of Paris's Chronica majora, which is based on what may be the only autograph manuscript of the text, the nineteenth-century historian Henry Richards Luard included the transcription of a now illegible note from the lower margin of the folio on which Paris described the tortures that Jews allegedly inflicted on Hugh of Lincoln. According to Luard, the note read: “... the Jews ... to circumcise .... and to call the circumcised [child] 'Jesus" (... Judaei circumcidere et circumcisum Jesum vocare). ${ }^{87}$ It seems that Paris wanted to add that, at some point in the process of abusing Hugh, the Jews circumcised him and started to call him "Jesus." 88

In explaining that the Jews circumcised Hugh and then started to address him as "Jesus," this note provides a clue to yet another way-the last one that

86 See Eric M. Zafran, "The Iconography of Anti-Semitism: A Study of the Representations of the Jews in the Visual Arts of Europe, 1400-160o" (Ph.D. Diss. New York University, 1973), 32-33; Ruth Mellinkoff, Outcasts: Signs of Otherness in Northern European Art of the late Middle Ages, 2 vols. (Berkeley: University of California Press, 1993), plate II. 23 and the discussion at 1:43 and 1:106-7; Areford, The Viewer, 223 n. 103.

87 British Library, Royal MS ${ }_{14}$ C viI, fol. 176v, transcribed in Paris, Chronica majora, 5:517 n. 1. On the identity of Matthew Paris's handwriting, see Richard Vaughan, "The Handwriting of Matthew Paris," Transactions of the Cambridge Bibliographical Society 1 (1953): 376-94. I am grateful to Justin Clegg, curator of medieval literary manuscripts at The British Library, for discussing this material with me. Efforts to examine the faded notes in this manuscript using ultraviolet and infrared light have led to the conclusion that Luard's readings were accurate and that they are the best record of these notes, pending the development of more advanced imaging techniques (4 September 2014).

88 The notion that Jews circumcised Hugh of Lincoln did not make it into the ballads that were later composed about Hugh or into Chaucer's “Prioress's Tale." There may, however, be some evidence of awareness of Paris's note across the ages. In the nineteenth century, the Scottish intellectual Robert Chambers (d. 1871) wrote that Matthew Paris "state[d] that the Jews of Lincoln circumcised and crucified a Christian child in $125^{\circ}$ [probably meaning 1255] at whose tomb miracles were performed" (Robert Chambers, The Book of Days: A Miscellany of popular antiquities, 2 vols. [London: W. and P. Chambers, 1888], 1:447). 
we shall address - in which thirteenth-century Christians could have understood circumcision as functioning as a prelude to ritual murder. The act of circumcision could have signaled the moment at which the victim started to become "like Christ," while marking him with a permanent physical likeness to Christ. One scholar has offered a related interpretation of the circumcision in the Norwich case: Abraham Gross has suggested that Christians might have imagined that Norwich Jews, wanting to "repeat the crucifixion of Jesus," found it necessary first to "make [the boy] Jewish [by circumcising him]." ${ }^{89}$ Discussing the alleged circumcision of Simon of Trent, David Areford similarly has suggested that Simon's "circumcision [wa]s a moment that both strip[ped] the boy of his Christianity (by physically marking him as a Jew) and seal[ed] his identification with Jesus." ${ }^{00}$ To my knowledge, the marginal note in the autograph manuscript of Paris's Chronica majora that explicitly links Jews circumcising Hugh of Lincoln to Jews starting to address Hugh as "Jesus" provides the first textual corroboration for this kind of understanding of the role of circumcision..$^{91}$

This interpretation of the role of circumcision resonates with two key thirteenth-century developments. First, it relates to practices pertaining to imitatio Christi. These could involve ethical behavior, preaching, poverty, and chastity, and they could also involve intense focus on Christ's body, leading to mystical assimilation into Christ's physicality and to taking on Christ's bodily sufferings with striking literalism-for instance, by receiving the stigmata. ${ }^{92}$ For an array of reasons, including attitudes toward the Old Law and concerns about Judaizing, circumcision was not a manner in which Christians considered it appropriate to imitate the body of Christ. ${ }^{93}$ Nevertheless, Christians who were accustomed to the notion of imitating the body of Christ could well have imagined that Jews would have engaged in this unseemly kind of likening. ${ }^{94}$

Second, this interpretation of the role of circumcision in the context of a ritual murder resonates with thirteenth-century views that the purported victims

89 Gross, "The Blood Libel," 173 n. 10.

9o Areford, The Viewer, 199 .

91 See Areford, The Viewer, 199 and Gross, "The Blood Libel," 173 n. 10.

92 Bynum, Fragmentation and Redemption, 143-46; Giles Constable, Three Studies in Medieval Religious and Social Thought: The Interpretation of Mary and Martha, the Ideal of the Imitation of Christ, the Orders of Society (Cambridge: Cambridge University Press, 1995), $143-248$.

93 Murphy, "Concern about Judaizing."

94 The possibility that the corpse of an alleged victim of ritual murder would, over time, begin to manifest the stigmata appears in Paris's account of the alleged discovery, in St. Benedict's cemetery in London in 1244, of the corpse of a boy on whose body Hebrew letters were inscribed (Paris, Chronica majora, 4:377-78). 
of Jewish ritual murders actually became Christ. ${ }^{95}$ Earlier ritual murder narratives (as well as some contemporaneous and later ones) maintained-and portrayed Jews as maintaining - a clear distinction between the bodies of Jews' purported contemporary victims and that of Christ. ${ }^{96}$ Starting in the thirteenth century, however, some ritual murder narratives began to suggest a more complex view. The manuscript mentioned above that relates the story of the crucifixion of Adam of Bristol, for example, at some points portrays Jews as distinguishing between Adam and Christ; yet, at others, it portrays Jews as identifying Adam with Christ. A distinction between the bodies of Adam and Christ is apparent, for instance, when a Jew named Samuel tells Adam: "You will suffer a more painful death because of Christ your God." But Samuel seems to identify Adam with Christ in his repeated references to Adam as the "God of the Christians," and when he boasts (referring to previous ritual murders) that Adam was the fourth "God of the Christians" whom he had crucified. ${ }^{97}$ In a culminating moment, the Christian author even cast God as confirming that Adam was indeed Christ. From on high, and in Hebrew no less, God bellows: "I am the God of Abraham, Isaac, and Jacob, whom for the fourth time you have crucified." 98

95 See Stacey, "Ritual Crucifixion;" Kenneth Stow, Jewish Dogs: An Image and its Interpreters (Stanford: Stanford University Press, 2006), 60-70; Kenneth Stow, "The Cruel Jewish Father: From Miracle to Murder," in Studies in Medieval Jewish Intellectual and Social History: Festchrift in Honor of Robert Chazan, ed. David Engel, Lawrence Schiffmann, and Elliot R. Wolfson (Leiden: Brill, 2012), 245-78, at 253-57. Stacey argues that the increasing identification of Jews' purported victims with Christ corresponded to the movement of ritual murder stories beyond their original monastic milieu (Stacey, "Ritual Crucifixion," 19-21). On the convergence of the themes of eucharistic devotion and anti-Judaism, also see Leah Sinanoglou, "The Christ-Child as Sacrifice," Speculum 43 (1973): 491-509; Denise Despres, "Cultic Anti-Judaism and Chaucer's Little Clergeon," in Modern Philology 91 (1994): 413-27; Denise Despres, "Mary of the Eucharist: Cultic Anti-Judaism in Fourteenth-Century English Devotional Manuscripts," in From Witness to Witchcraft:Jews and Judaism in Medieval Christian Thought, ed. Jeremy Cohen (Wiesbaden: Harrassowitz Verlag, 1996), 375-401.

96 This distinction is clear, for instance, in the vita of William of Norwich, in which the Jews who allegedly crucified William declare: "Just as we have condemned Christ to a most shameful death, so we condemn a Christian, so that we punish both the Lord and his servant in the punishment of reproach" (Life and Passion, 17). On this distinction in the passio of Oberwesel (1287), see Stow, "The Cruel Jewish Father," 253-54; Stow, Jewish Dogs, $60-70$.

97 Cluse, "Fabula Ineptissima," 308.

98 Cluse, "Fabula Ineptissima," 310. See discussion in Stacey, "Ritual Crucifixion;" Hames, "The Limits of Conversion;" Uri Shachar, "Inspecting the Pious Body: Christological Morphology and the Ritual-Crucifixion Allegation," Journal of Medieval History 41 (2015): 1-20, at $17-18$. 
While it does seem that Paris, at some point, envisioned circumcision as a Jewish means of making Hugh of Lincoln more like Christ, there is no indication that this was how he or Wendover conceived of Edward's circumcision. However, it is possible that these chroniclers and some of their readers imagined that Edward's circumcision served to make Edward more like Christ, and perhaps even to mark his becoming an embodiment of Christ. Both interpretations align with contemporaneous developments in Christian thought and devotional practices. In addition, they would have been compatible with viewing Edward's circumcision as a parody of the circumcision of Christ and as an illustration of Jewish cruelty.

It is ultimately impossible to know how Wendover and Paris came to write that Jews circumcised a boy in anticipation of crucifying him, let alone what their thirteenth-century readers made of this claim, two centuries before this trope gained currency. As we have seen, a number of interpretations are conceivable in the context of the thirteenth century. Edward's circumcision could have functioned as a form of torture, as a parody of the circumcision of Christ, and as a way of making Edward physically more like Christ. These interpretations are mutually compatible. Moreover, like the references to circumcision in the context of conversion to Judaism, surveyed above, they all reinforce the view that Jews were the archenemies of Christians and the Christian faith. Jews inflicted pain and suffering on the historical Christ, and they were determined to reenact Christ's passion and to physically and spiritually injure Christ's flock.

In light of these reflections, the "conversion" and "ritual murder" versions of Edward's case no longer seem quite so startling or disparate. The alleged Jewish circumcision of a Christian child could conjure thoughts of Jewish proselytizing and of ritual murder, and Christians deemed both phenomena to be vicious forms of Jewish attack. Indeed, it is significant that both the records of the judicial proceedings pertaining to Edward's case and Paris's longer Chronica majora account dwelled on the anti-Christian tenor of the Jews' imputed actions. The court records specified that Norwich Jews circumcised Edward "in contempt of the cross and Christianity," and they went on to explain that, as Edward's circumcision pertained "to matters of faith," it merited adjudication by ecclesiastical authorities. ${ }^{99}$ For his part, Paris noted, as quoted above, that bishop William of Ralegh understood the Jews' crime to have constituted "a wounding of the faith" ( fidei laesione). ${ }^{100}$ Transposed onto a Christian body,

99 Curia Regis Roll 115b, 18 Henry III, m. 22.

100 Paris, Chronica, 4:30-31. 
circumcision was one more way in which — starting in the thirteenth centuryChristians imagined Jews harming Christians.

\section{Acknowledgements}

I am grateful to the institutions and colleagues whose support and feedback shaped this article. I presented early versions at the Jewish History Colloquium at Yale University, at the Concilium Lateranense IV conference in Rome, at Samantha Kelly's graduate seminar in the History Department at Rutgers University, and at Forum Ashkenaz at The Hebrew University of Jerusalem. Elisheva Baumgarten, Nomi Benin Clark, Caroline Walker Bynum, Adam Cohen, Naama Cohen-Hanegbi, Tamar Herzig, Marcia Kupfer, Micha Perry, Irven Resnick, Ephraim Shoham-Steiner, Robert C. Stacey, Kenneth Stow, Kathleen Walkowiak, Elad Zamir, and the anonymous reviewers provided invaluable assistance and suggestions. 